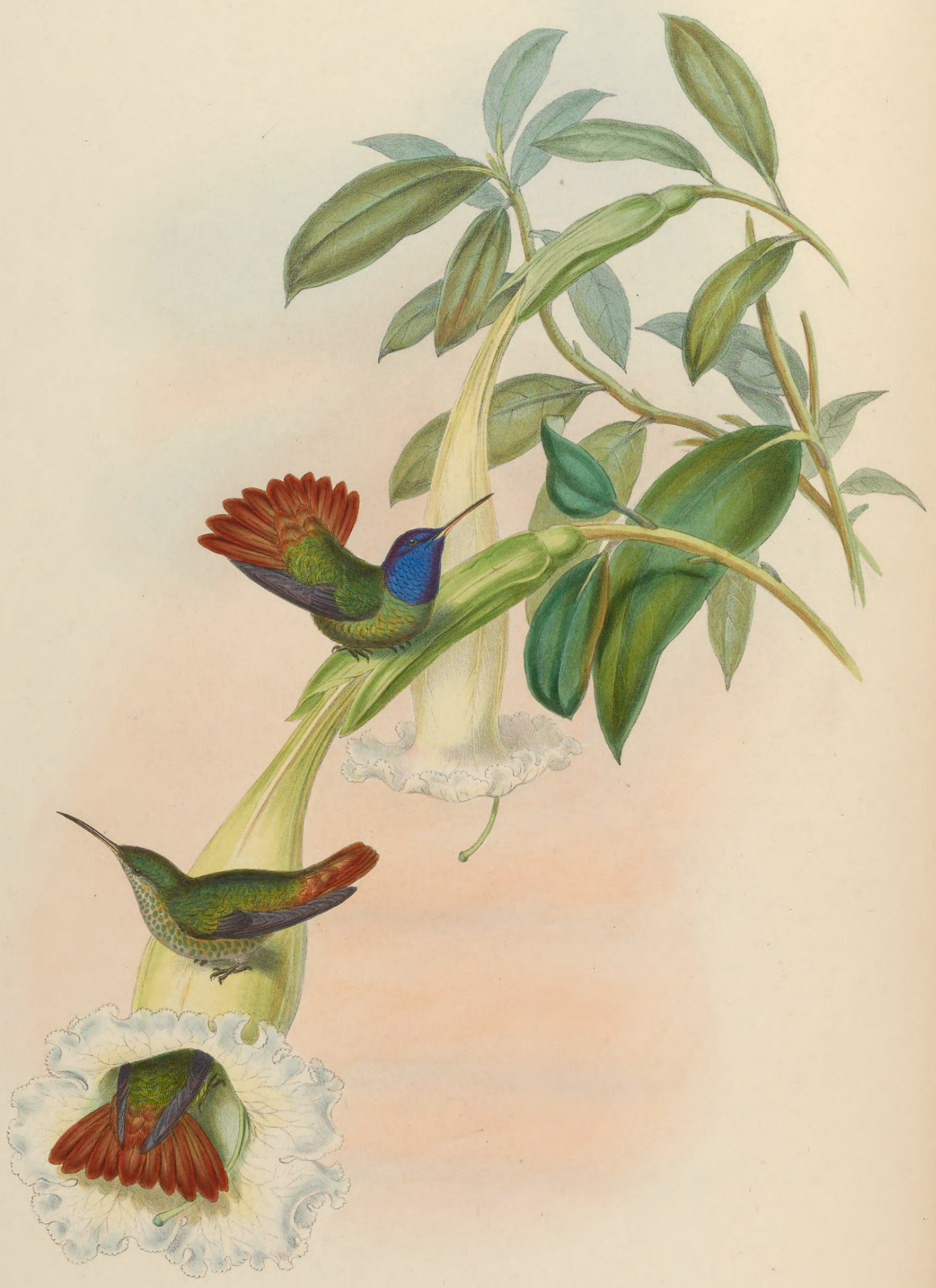




\section{CHRYSURONIA OENONE.}

\section{Enone Humming-bird.}

Ornismya Oenone, Less. Hist. Nat. des Ois. Mou. Supp., p. 157. pl. 30.

Enone, Ib. Ind. Gen. et Syn. des Ois. du Gen. Trochilus, p. xl.

oenone, De Latt. et Bourc. Rev. Zool. 1839, p. 17.

Polytmus Enone, Gray and Mitch. Gen. of Birds, vol. i. p. 109, Polytmus, sp. 80.

Chrysuronia aenone, Bonap. Consp. Gen. Av., p. 75, Chrysuronia, sp. 1.

Oenone, Reich. Auf. der Col., p. 9.

anone, Bonap. Rev. Zool. 1854, p. 254.-Sclater in Proc. of Zool. Soc., part xxii.

p. 111.

THIs very charming Humming-bird does not, I believe, inhabit Trinidad, as stated by Lesson; it is true that specimens frequently come direct from thence; but, according to Mr. Tucker, a gentleman long resident on the island, and who has paid great attention to its Humming-birds, these specimens are sent thither from the neighbouring parts of the South American Continent. All the countries traversed by the streams of the Orinoco are probably favoured with its presence; and I think it likely that it also ranges all over the great country of Venezuela, since specimens are sent in tolerable abundance from several of the intervening districts between the Orinoco and the high lands of Columbia. It very frequently occurs in collections from Bogota and other Andean districts lying within an area of 500 miles from the city of Santa Fé ; I have also received it direct from the Napo; it is evident therefore that it enjoys a very wide range of habitat. It may fairly be considered as one of the finest species of the genus Chrysuronia, the members of which are distinguished by their rich bronze-coloured tails, and by a brilliant blue colouring about the head, which in some species decorates the crown alone, while in others, as in the present bird, it extends over the whole of the throat and neck.

The sexes appear to differ considerably in their colouring, the female being devoid of the blue on the head, while in the distinguishing feature of the group, the bronzy tail, she is scarcely less beautifully adorned.

The male has the entire head and throat rich deep shining blue; all the upper surface and wing-coverts lively golden green; wings purplish brown; upper and under tail-coverts and tail rich golden bronze; under surface shining grass-green; upper mandible and tip of the lower mandible black, the basal two-thirds of the latter flesh-colour.

The female has the head green; upper surface golden green; wings purplish brown; upper tail-coverts and tail coppery bronze; under surface white, spangled with shining green; vent white.

The figures are of the size of life. The plant is the Solandra lavis. 


\section{$2 \mathrm{BHL}$ Biodiversity Heritage Library}

Gould, John. 1861. "Chrysuronia œnone, CEnone Humming-bird. [PI. 325]." A monograph of the Trochilidae, or family of humming-birds 5, https://doi.org/10.5962/p.317134.

View This Item Online: https://www.biodiversitylibrary.org/item/108806

DOI: https://doi.org/10.5962/p.317134

Permalink: https://www.biodiversitylibrary.org/partpdf/317134

\section{Holding Institution}

Smithsonian Libraries

\section{Sponsored by}

Smithsonian Institution Libraries

\section{Copyright \& Reuse}

Copyright Status: NOT_IN_COPYRIGHT

This document was created from content at the Biodiversity Heritage Library, the world's largest open access digital library for biodiversity literature and archives. Visit BHL at https://www.biodiversitylibrary.org. 